Między wykluczeniem a dobrobytem. Refleksja nad społeczną myśla encykliki „Centesimus annus” Jana Pawła II, red. B. Bąk,

R. Kantor, M. Kluz, J. Młyński, Kraków 2017, s. 263-276.

DOI: http://dx.doi.org/10.15633/9788374386289.12

Ks. dr Bartosz Bąk

Wikariusz parafii bł. Karoliny w Tarnowie,

wykładowca w Tarnowskiej Szkole Wyższej

\title{
Konieczność formacji
}

w duchu chrześcijańskim

twórców i pracowników

środków społecznego przekazu.

Refleksja pastoralna w oparciu o encyklikę

papieża Jana Pawła II Centesimus annus

oraz inne dokumenty Kościoła

W Księdze Rodzaju czytamy, że Bóg nakazał ludziom czynić sobie ziemię poddaną ${ }^{1}$. W ten sposób złożył na ręce człowieka współodpowiedzialność za kształtowanie rzeczywistości, w której dane jest mu żyć. Owa współodpowiedzialność polega przede wszystkim na trosce o to, co już istnieje dzięki dobroci Boga, jak również na nadawaniu nowszego wyrazu rzeczom, którymi człowiek się posługuje i które wymagają udoskonalenia bądź przystosowania do zmieniającej się

1 Rdz 1, 28: „Po czym Bóg im pobłogosławił, mówiąc do nich: «Bądźcie płodni i rozmnażajcie się, abyście zaludnili ziemię i uczynili ją sobie poddaną; abyście panowali nad rybami morskimi, nad ptactwem powietrznym i nad wszystkimi zwierzętami pełzającymi po ziemi»". 
rzeczywistości. Wyrazem takiego nowego spojrzenia okazała się dla Kościoła i świata encyklika papieża Jana Pawła II Centesimus annus, napisana w 100. rocznicę ogłoszenia encykliki papieża Leona XIII Rerum novarum. Pod koniec XIX wieku papież Leon XIII przestrzegał współczesny mu świat przed rodzącym się komunizmem, a także, obserwując rozwój gospodarczy świata, nauczał o konieczności humanizacji życia gospodarczego, a tym samym życia w ogólności. Po upływie stu lat wiele z przewidywań papieża Leona XIII się spełniło, wiele z nich okazało się zabójczych dla człowieka i jego godności, $\mathrm{z}$ wieloma ludzie nie potrafili sobie poradzić, ulegając pokusie łatwego i szybkiego zysku, wykorzystywania drugiego człowieka do realizacji partykularnych interesów lub prowadzenia życia bez większych wymagań moralnych. Z tego też względu papież Jan Paweł II, doceniając wielką rolę encykliki Rerum novarum, sam zabrał głos w refleksji nad katolicką nauką społeczną w encyklice Centesimus annus. Był to swoisty hołd złożony czcigodnemu poprzednikowi, ale również chęć pogłębienia nauki Leona XIII i przedstawienia pewnych zjawisk w nowym świetle przez pisanie o tzw. „rzeczach nowych”. Taką intencją kierował się papież Jan Paweł II, pisząc ową encyklikę².

\section{Kultura wyzwaniem dla współczesności}

Jednym z tematów opisywanych przez Jana Pawła II jest zjawisko kultury jako przestrzeni, w której powinno rozwijać się i kształtować życie współczesnych ludzi. Owa odpowiedzialność spoczywa przede

2 Jan Paweł II, Encyklika Centesimus annus [dalej: CA], 3: „Obecnie pragnę zaproponować «odczytanie na nowo» encykliki Papieża Leona XIII, zachęcając do «spojrzenia wstecz», to jest na jej tekst, aby sobie uświadomić bogactwo sformułowanych w niej fundamentalnych zasad, dotyczących rozwiązania kwestii robotniczej. Ale zachęcam też do «spojrzenie dokoła» na «rzeczy nowe», które nas otaczają i w których jesteśmy - by tak rzec - zanurzeni, a które znacznie różnią się od «rzeczy nowych», charakteryzujących ostatnie dziesięciolecie ubiegłego wieku". 
wszystkim na instytucji państwa, która wchodzi w swoistą korelację z całą przestrzenią życia człowieka, którą można określić mianem kultury. Papież tym samym wyraził troskę o demokratyzację społeczeństwa, przestrzeganie praw człowieka do życia i godziwego rozwoju, zapewnienie obywatelom miejsc pracy i wynagrodzenia, jak również prawa do wolności w wyznawanych poglądach, w tym również do religii (zob. CA 44-52).

Papież Jan Paweł II stwierdził, że wszelka ludzka działalność dokonuje się w jakimś określonym obszarze kultury. Stąd należy domagać się, aby z jednej strony cały człowiek włączył się w tworzenie owej przestrzeni życia, czynił ją bardziej dojrzałą i świadomą swojego posłannictwa, $\mathrm{z}$ drugiej strony zaś by ta przestrzeń sama przenikała człowieka ${ }^{3}$.

Współczesna kultura przybiera różnobarwne formy, począwszy od tzw. kultury wyższej, którą tworzą wystawy, koncerty muzyki klasycznej, wieczory poezji czy sztuki teatralne, a skończywszy na tzw. kulturze masowej, reprezentowanej przez artystów docierających ze swoim przekazem do szerokich mas odbiorców. Ta ostatnia zajmuje istotne miejsce we współczesnych środkach społecznego przekazu. Tym samym zarówno media, jak i twórcy oraz pracownicy związani z kulturą masową stają się twórcami lub współtwórcami całej współczesnej rzeczywistości kulturalnej. Osoby odpowiedzialne za przekaz medialny, zarówno laicki, jak i religijny, stają się równocześnie współodpowiedzialni za właściwe ich wykorzystanie przez współczesnego odbiorcę oraz za godną promocję kultury i wartości ogólnoludzkich.

Tworzenie kultury jest jedną z działalności charakterystycznych dla człowieka. Do prawdziwego i pełnego człowieczeństwa dochodzi

3 CA 51: „Rzeczywiste kształtowanie się kultury wymaga włączenia się całego człowieka, który wyraża w niej swój zmysł twórczy, inteligencję, znajomość świata i ludzi. Angażuje w nią także swą umiejętność panowania nad sobą, osobistego poświęcenia, solidarności i pracy dla rozwoju dobra wspólnego". 
się nie inaczej jak właśnie poprzez kulturę, rozumianą jako kultywowanie dóbr i wartości naturalnych. Kultura w sensie ogólnym jest tym wszystkim, w czym człowiek doskonali i rozwija różnego rodzaju talenty i uzdolnienia. Dzięki temu obejmuje on świat we władanie, podążając drogą poznania i pracy. Rozwijanie własnych zdolności służy równocześnie rozwojowi rodziny i całego społeczeństwa poprzez postęp w dziedzinie obyczajów. Człowiek przez dzieła, jakich dokonał na przestrzeni wieków, wyraża, przekazuje i zachowuje bogate doświadczenie duchowe, które w konsekwencji służy wszystkim ludziom (LdR 53).

\section{Formowanie „od środka” środowiska medialnego}

Twórcy i pracownicy środków społecznego przekazu w znaczący sposób przyczyniają się do zachowywania i tworzenia kultury. Dlatego sami potrzebują również odpowiedniej formacji, aby mogli wykonywaną przez siebie pracę czynić jeszcze bardziej ludzką, czyli ukierunkowaną na rozwój dobra drugiego człowieka i przekazywanie mu wartości, które będą ubogacać jego życie.

W całym procesie formacji do odpowiedzialnego tworzenia rzeczywistości środków społecznego przekazu znaczącą rolę odgrywa Kościół. Stara się bowiem przypominać, że tylko w oparciu o jasne zasady i wartości jest możliwy zdrowy i dojrzały postęp w dziedzinie mediów, a ich twórcy i pracownicy mają obowiązek kierowania się wartościami moralnymi, poszanowaniem godności osoby ludzkiej, jej wolności i prawa do świadomego decydowania o tym, czego człowiek chce słuchać, oglądać i o czym chce czytać.

Formacja chrześcijańska środowiska twórców i pracowników mediów nie ma na celu ograniczania szeroko pojętej twórczości człowieka, ale chce przychodzić z pomocą w tych wszystkich sytuacjach, w których działania ludzi odpowiedzialnych za współczesny przekaz 
medialny mogą przyczyniać się raczej do destrukcji człowieka niż do jego rozwoju.

Kościół w swoim nauczaniu w wielu miejscach odnosi się bezpośrednio do twórców i pracowników środków społecznego przekazu. W ten sposób pokazuje, że nie jest mu obojętne, jak rozwija się ten wymiar życia kulturalnego, jakie zasady i wartości w nim obowiązują oraz jakie należy podejmować działania, by pracę ludzi branży medialnej jeszcze bardziej ukierunkować na dobro i poszanowanie godności każdego człowieka. Kościół myśli o twórcach i pracownikach środków społecznego przekazu z wielką troską, z należnym im szacunkiem i modli się za nich ${ }^{4}$.

Punktem wyjścia formacji środowiska środków społecznego przekazu jest przypomnienie podstawowej przesłanki, a mianowicie, że twórcy szeroko rozumianej kultury poprzez swoją działalność zawodową i artystyczną mogą prowadzić ludzi do dobra lub zła. Na nich bowiem ciąży szczególna odpowiedzialność moralna za tych wszystkich, którzy korzystają z owoców ich pracy lub działalności twórczej ${ }^{5}$. Wszelkie działanie przez nich podejmowane ma służyć dobru wspólnemu i w tej perspektywie należy widzieć wszystkie aspekty natury ekonomicznej, politycznej i artystycznej ich pracy.

Twórcy i pracownicy środków społecznego przekazu powinni wstępować do różnego rodzaju związków zawodowych, które zobowiązują swoich członków do szanowania praw i zasad moralnych w wykonywaniu pracy zawodowej i artystycznej oraz nakładają

4 Jan Paweł II, Orędzie Papieskie na Dzień Środków Społecznego Przekazu. Rola komunikacji społecznej wobec zadań rodziny (1980), 60, w: Orędzia papieskie na Światowe Dni Komunikacji Społecznej 1967-2002, red. M. Lis, Częstochowa 2002, s. 95.

5 Sobór Watykański II Dekret o środkach społecznego przekazywania myśli Inter mirifica [dalej: IM], 11: „Szczególny obowiązek moralny odnośnie do właściwego korzystania ze środków społecznego przekazu ciąży na dziennikarzach, pisarzach, aktorach, reżyserach, producentach, nakładcach, pracownikach rozpowszechniania, zarządzających tymi środkami i sprzedawcach, na krytykach i w ogóle na wszystkich, którzy w jakikolwiek sposób przyczyniają się do przygotowania i przekazywania programów". 
obowiązki opisane w kodeksach zawodowych (por. IM 11). Do takich związków zawodowych zaliczają się m.in. Europejska Federacja Dziennikarzy, Stowarzyszenie Dziennikarzy Polskich, Stowarzyszenie Dziennikarzy Rzeczypospolitej Polskiej, Stowarzyszenie Pisarzy Polskich oraz Katolickie Stowarzyszenie Dziennikarzy.

Pracownicy środków społecznego przekazu, wykonując swoją pracę, niejednokrotnie realizują taką samą misję względem społeczeństwa, jak nauczyciele względem uczniów, stając się wychowawcami $^{6}$. Czasem ich odpowiedzialność jest większa, bo dysponują potężnymi narzędziami technicznymi. Nie tylko edukują poprzez media, ale często kreują rzeczywistość, w której żyje współczesny człowiek. Tym bardziej potrzeba wrażliwości twórców i pracowników środków społecznego przekazu na wartości i treści, które przekazują. Media są codzienną szkołą dla wielu ludzi w zakresie wydarzeń, jakie dzieją się na świecie. Jeżeli pracownicy środków społecznego przekazu nie będą pamiętać o szanowaniu wartości i kierowaniu się w swojej pracy podstawowymi zasadami obowiązującymi w relacjach interpersonalnych, wykonywana przez nich praca będzie swoistą grą na losach ludzi, decydującą o ich „być albo nie być” 7 .

Pracownicy i twórcy środków społecznego przekazu nie mogą zapominać, że audytorium, do którego docierają, jest ogromne. $Z$ tego też powodu środki, jakimi się posługują, noszą nazwę „środków społecznego przekazu". Wszystko, co ci ludzie czynią, powinno dokonywać się w oparciu o zasadę odpowiedzialności za takie prowadzenie odbiorców, które będzie zmierzało do ich rozwoju i ubogacenia, do ich szczęścia i postępu ${ }^{8}$.

6 Zob. Paweł VI, Orędzie Papieskie na Dzień Środków Społecznego Przekazu. Komunikacja społeczna i młodzież (1970), 13, w: Orędzia papieskie..., dz. cyt., s. 27.

7 Paweł VI, Orędzie Papieskie na Dzień Środków Społecznego Przekazu. Środki komunikacji społecznej ważnymi elementami cywilizacji (1967), 3, w: Orędzia papieskie..., dz. cyt., s. 13.

8 Zob. Paweł VI, Orędzie Papieskie na Dzień Środków Społecznego Przekazu. Komunikacja społeczna a rodzina (1969), 11, w: Orędzia papieskie..., dz. cyt., s. 23. 
Do odpowiedzialności za wykonywaną pracę należy dołączyć również zasady bezstronności, uczciwości i obiektywizmu. Występują bowiem przypadki, w których środki społecznego przekazu znajdują się pod zarządem wielkich koncernów medialnych, narzucającego swoim pracownikom styl i sposób działania. Takie zabiegi stosowane przez właścicieli mediów mają na celu wpływanie na odbiorców. Można zatem mówić o wywieraniu presji na otoczenie i wykorzystywaniu ludzi do osiągania partykularnych celów (zob. CP 76). Z tym wiążą się manipulacja i kreowanie mód jako realizacja komercyjnych zamiarów.

Formacja pracowników i twórców środków społecznego przekazu do kierowania się zasadami i wartościami moralnymi w wykonywanej przez nich pracy jest bardzo ważna ze względu na powszechnie występujące zjawisko wykorzystywania mediów do celów komercyjnych i czysto zarobkowych. Niejednokrotnie również powodem takich działań jest chęć zdobycia popularności wśród ludzi. Wszystkie takie działania w rzeczywistości wyrządzają krzywdę odbiorcom traktowanym przedmiotowo, jako źródło zysku. Sami natomiast twórcy i właściciele mediów narażają się na utratę szacunku dla wykonywanego przez nich zawodu czy wręcz na okrycie się złą sławą w oczach społeczeństwa (zob. CP 77) ${ }^{9}$.

Producenci, twórcy i pracownicy środków społecznego przekazu muszą odznaczać się odwagą w propagowaniu takich wartości, które promują godność człowieka i przyczyniają się do jego rozwoju. To nie chęć zysku albo zwiększenia popularności powinny być wyznacznikami ich pracy. To właśnie im przypada obecnie w udziale trudny obowiązek wychowywania odbiorców do poznawania i doceniania tych wartości, które nie są dostatecznie znane i promowane w społeczeństwie. Propagowanie takich wartości buduje autentyczną dumę i siłę społeczeństw, a jego owocami są choćby rozwój pokoju

9 Zob. Paweł VI, Orędzie Papieskie na Dzień Środków Społecznego Przekazu. Środki komunikacji społecznej w służbie jedności ludzi (1971), 20, w: Orędzia papieskie..., dz. cyt., s. 34-35. 
na świecie, poświęcenie dla wzniosłych ideałów, ofiarność i heroizm w sprawach codziennych ${ }^{10}$.

Ludzie kultury i świata mediów potrzebują nie tylko wsparcia duchowego od Kościoła, lecz także kompetentnej pomocy i właściwej formacji chrześcijańskiej. Miłość i służbę człowiekowi powinni przedkładać nad wszelkie inne korzyści, dając do zrozumienia wszystkim odbiorcom, jaki przyświeca im cel i ideał pracy twórczej ${ }^{11}$.

\section{Rola mediów katolickich we współczesnym świecie}

Środki społecznego przekazu i ich twórcy, kształtując współczesną opinię publiczną, wpływają równocześnie na kształtowanie obrazu Kościoła. Od nich zależy, w jaki sposób społeczeństwo będzie pojmowało jego naturę, posłannictwo i dzieło. Wiele osób redukuje rzeczywistość eklezjalną tylko i wyłącznie do instytucji. Tym samym zapomina o tym, co istotne, a mianowicie że Kościół jest także rzeczywistością, która wciela w życie miłość Boga i niesie ludziom przesłanie Chrystusa ${ }^{12}$. W przypominaniu o tym wyjątkową rolę odgrywają wszystkie media katolickie.

W XX wieku w Kościele katolickim nastąpiło ożywienie działalności środków społecznego przekazu. Oprócz gazet zaczęły powstawać i rozwijać się radio i telewizja. Po Soborze Watykańskim II dokonała

10 Jan Paweł II, Orędzie Papieskie na Dzień Środków Społecznego Przekazu. Komunikacja społeczna w służbie pokoju (1983), 76, w: Orędzia papieskie..., dz. cyt., s. 117-118; Paweł VI, Orędzie Papieskie na Dzień Środków Społecznego Przekazu. Komunikacja społeczna a rodzina (1969), dz. cyt., 11, s. 23.

11 Zob. Paweł VI, Orędzie Papieskie na Dzień Środków Społecznego Przekazu. Komunikacja społeczna wobec podstawowych praw i obowiq̨zków człowieka (1976), 44, w: Orędzia papieskie..., dz. cyt., s. 66.

12 Jan Paweł II, Orędzie Papieskie na Dzień Środków Społecznego Przekazu. Kształtowanie opinii publicznej (1986), 93, w: Orędzia papieskie..., dz. cyt., s. 144. 
się zmiana nastawienia do mediów - od nieufności, a nawet wrogości, do akceptacji, a nawet afirmacji.

W latach 60. XX wieku ojcowie soborowi zachęcali do rozwijania i promowania prasy katolickiej, która była wówczas najmocniejszym środkiem służącym głoszeniu nauki chrześcijańskiej ${ }^{13}$. Zachęcali równocześnie, aby w pełni popierać rozwijającą się kinematografię, a zwłaszcza filmy, które mogły służyć godziwej rozrywce. Należało więc wspierać i łączyć w związki kina prowadzone przez katolickich przedsiębiorców. Kościół zachęcał także, by promować takie audycje radiowe, które byłyby odpowiednie dla rodzin katolickich, pomagały uczestniczyć w życiu Kościoła i uczyły prawd religijnych. ozpoczęto więc zakładanie katolickich stacji radiowych, charakteryzujących się odpowiednio wysokim poziomem audycji (por. IM 14).

Dokument soborowy Inter mirifica jest podstawowym źródłem rozwoju myśli kościelnej w dziedzinie środków społecznego przekazu na przestrzeni ostatnich pięćdziesięciu lat. $\mathrm{W}$ nim bowiem znajduje się zachęta do tworzenia, rozwijania i wspomagania mediów katolickich. Ojcowie Soboru Watykańskiego II stwierdzili wręcz, że byłoby rzeczą niegodziwą, gdyby Kościół patrzył bezczynnie, jak rozwijają się współczesne środki przekazu, i nie są wykorzystywał ich w głoszeniu orędzia chrześcijańskiego. Przeszkodą, która nie powinna w żaden sposób krępować rozwoju mediów katolickich, były ogromne wydatki związane z ich funkcjonowaniem. Dlatego ojcowie soborowi zwrócili się do wszystkich ludzi dobrej woli, a zwłaszcza do autorytetów w dziedzinie ekonomii i techniki, by zechcieli wspierać w miarę swoich możliwości te środki społecznego przekazu, które służą promocji kultury i apostolstwu (zob. IM 14).

13 IM 14: „Przede wszystkim należy popierać dobrą prasę. Aby zaś przepoić czytelników w pełni duchem chrześcijańskim, należy też tworzyć i rozwijać prawdziwie katolicką prasę, która (...) niech wychodzi wyraźnie w tym celu, aby urabiać, umacniać i popierać opinię publiczną zgodną z prawem naturalnym, nauką i nakazami katolickimi, oraz by podawać do wiadomości i należycie wyjaśniać fakty dotyczące życia Kościoła". 
Instrukcja pastoralna Communio et progressio poświęciła dużo uwagi wyjaśnieniu, dlaczego środki społecznego przekazu należy wykorzystywać w służbie głoszenia Ewangelii. Podkreśliła także, że kluczową rolę w tej dziedzinie odgrywają ludzie świeccy, którzy żyjąc zgodnie Z wartościami chrześcijańskimi, powinni tchnąć tego ducha w środowiska, w których pracują ${ }^{14}$. Do kompetencji poszczególnych konferencji episkopatów i biskupów diecezjalnych należy wprowadzanie tych sugestii w życie. Jan Paweł II w orędziu z 1991 roku zachęcił wszystkich katolików działających w mediach, jak również pasterzy Kościoła, aby ciągle przypominali sobie zasady i wskazania wyłożone w Communio et progressio oraz innych dokumentach poświęconych temu zjawisku ${ }^{15}$.

Wiernym świeckim pracującym w środkach społecznego przekazu należy nieustannie przypominać, jak wielka spoczywa na nich odpowiedzialność, by w miejscu pracy słowem i przykładem głosili naukę Jezusa Chrystusa. Dlatego cała wspólnota Kościoła powinna nieustannie modlić się za pracowników mediów, aby nie ustawali w realizacji chrześcijańskiego powołania. Skoro należy głosić Ewangelię za pomocą wszystkich środków społecznego przekazu, tym bardziej trzeba to czynić, wykorzystując media katolickie. Nie można dopuszczać do sytuacji, by pojawiały się zaniedbania powstałe przez opieszałość lub niechęć ze strony duchownych lub organizacji katolickich. W tym celu należy dokonać uwzględnienia czynnika koordynacji działań pomiędzy różnymi strukturami kościelnymi, posługującymi się środkami społecznego przekazu ${ }^{16}$.

14 Temu zagadnieniu poświęcony został rozdział trzeci Instrukcji zatytułowany: Działalność i przedsięwzięcia katolików w wykorzystaniu poszczególnych środków przekazu. Można w nim odnaleźć sugestie, jak jeszcze skuteczniej i sprawniej posługiwać się współczesnymi środkami przekazu w realizacji zadania głoszenia Ewangelii i nauki katolickiej.

15 Jan Paweł II, Orędzie Papieskie na Dzień Środków Społecznego Przekazu. Środki komunikacji w służbie jedności i postępu rodziny ludzkiej (1991), 119, w: Orędzia papieskie..., dz. cyt., s. 178.

16 Jan Paweł II, Orędzie Papieskie na Dzień Środków Społecznego Przekazu. Głoszenie orędzia Chrystusa w środkach komunikacji (1992), 123, w: Orędzia papieskie..., dz. cyt., s. 184-186. 
Już w orędziu z 1989 roku papież Jan Paweł II wymienił bardzo dokładnie różnego rodzaju narzędzia medialne, za pomocą których można i trzeba głosić Ewangelię:

Niechaj orędzie religijne i religijne inicjatywy będą obecne w środkach przekazu wszelkiego typu: w środkach audiowizualnych, kinematografii, w „pamięciach”, informatycznej wymianie banków informacji, w przedstawieniach teatralnych, stojących na wysokim poziomie widowiskach kulturalnych, w debatach i rozważaniach na temat spraw bieżących, w programach formacyjnych oraz wychowawczych, w kulturze masowej, dzięki wartościowym filmom animowanym i komiksom oraz dzięki szerokim możliwościom, jakie stworzą użycie druku, zapisu dźwiękowego i wizualnego, w momentach relaksu przy muzyce nadawanej przez rozgłośnie lokalne lub o dużym zasięgu ${ }^{17}$.

Jedną z kluczowych spraw w odniesieniu do mediów katolickich jest umożliwienie czynnego uczestniczenia w życiu Kościoła wiernym świeckim poprzez transmisje uroczystości religijnych, szczególnie mszy świętych. Konstytucja soborowa Sacrosanctum concilium zachęca, by wszystkie transmisje Eucharystii, zarówno w radiu, jak i telewizji, były przeprowadzane w sposób dyskretny, z szacunkiem i godnością, pod kierunkiem osób kompetentnych, wyznaczonych przez poszczególnych biskupów (SC 20). Należy przeprowadzać je z najwyższą dbałością, zarówno pod względem technicznym, jak i liturgicznym, oraz uwzględnić różnorodność odbiorców, zwyczajów i zmysłu wiary, jeśli transmisje przekraczają granice jednego kraju. Takie audycje stanowią domenę mediów katolickich, które muszą odpowiadać na potrzeby ludzkie i duchowe współczesnego człowieka (por. CP 151-157). Oprócz transmisji mszy świętych ważną

17 Jan Paweł II, Orędzie Papieskie na Dzień Środków Społecznego Przekazu. Religia w środkach przekazu (1989), 112, w: Orędzia papieskie..., dz. cyt., s. 168. 
funkcję w rozwoju religijnym powinny spełniać katolickie serwisy informacyjne, dyskusje czy konferencje duchowe.

Wszystkie katolickie środki społecznego przekazu mają równocześnie za zadanie prowadzić właściwą politykę informacyjną. To także stanowi jeden z elementów formacji chrześcijańskiej do krytycznego korzystania ze środków społecznego przekazu. Polityka informacyjna polega na ukazywaniu odpowiednich motywacji, pozwalających zyskać właściwy osąd co do danej treści przekazu medialnego, tak aby człowiek mógł pozostać w zgodzie z nauczaniem i moralnością chrześcijańską. Tak prowadzone działania przyczyniają się do wzrostu samodyscypliny i odpowiedzialności przy wyborze konkretnych programów ${ }^{18}$.

Tworzenie katolickich środków społecznego przekazu służy również prowadzeniu działalności ekumenicznej. Istnieje potrzeba budowania postawy otwartości i dialogu pomiędzy religiami i wyznaniami, także z wykorzystaniem mediów. Jednym ze sposobów prowadzenia dialogu ekumenicznego za pomocą środków społecznego przekazu może być przystępowanie do organizacji katolickich promujących systematyczną współpracę ekumeniczną ${ }^{19}$. Jednakże szczegółowe wskazania co do sposobów i metod prowadzenia tego dialogu należy pozostawić samym duszpasterzom ${ }^{20}$.

18 Paweł VI, Orędzie Papieskie na Dzień Środków Społecznego Przekazu. Odbiorca komunikacji społecznej: oczekiwania, prawa i obowiq̨zki (1978), 52, w: Orędzia papieskie..., dz. cyt., s. 80-82; Zob. Jan Paweł II, Orędzie Papieskie na Dzień Środków Społecznego Przekazu. Telewizja w rodzinie: kryteria właściwego wyboru programów (1994), 127-130, w: Orędzia papieskie..., dz. cyt., s. 192-199; Jan Paweł II, Orędzie Papieskie na Dzień Środków Społecznego Przekazu. Kino - nośnik kultury i propozycja wartości (1995), 131-135, w: Orędzia papieskie..., dz. cyt., s. 200-207.

19 Por. Papieska Komisja Środków Społecznego Przekazu. Kryteria współpracy ekumenicznej (15.11.1971). Do takich organizacji katolickich można zaliczyć m.in. OCıC, MCS, UCIP, UNDA, biura narodowe i stowarzyszenia katolickie.

20 Por. Papieska Rada do spraw Środków Społecznego Przekazu, List Papieskiej Komisji do spraw Środków Społecznego Przekazu (24.05.1971), w: Kościół o środkach komunikowania myśli, oprac. J. Góral, K. Klauza, Częstochowa 1997, s. 274277 (Biblioteka „Niedzieli”, 54). 
Wpływ środków społecznego przekazu na życie współczesnego człowieka jest ogromny. Sposób głoszenia Ewangelii na przestrzeni ponad dwóch tysięcy lat zmienił się radykalnie. Niewątpliwe zalety nauczania bezpośredniego nie mogą deprecjonować innych dróg. Do takich należą media, o których papież Paweł VI napisał, że gdyby Kościół nie używał ich w dziele ewangelizacji świata, byłby „winny przed swoim Panem" (EN 45).

Powstanie społeczeństwa informacyjnego stało się prawdziwą rewolucją kulturową, w której to media są „pierwszym współczesnym areopagiem” (RM 37), na którym dokonuje się wymiana myśli, poglądów i wartości. Doświadczenie życia przy udziale środków społecznego przekazu jest równocześnie doświadczeniem Chrystusa i Jego nauki. Głosząc słowo Boże, Kościół zobowiązany jest do intensywnego i umiejętnego wykorzystywania własnych mediów przy równoczesnym odważnym i twórczym szukaniu nowych sposobów i metod działania ${ }^{21}$.

\section{Zakończenie}

Środki społecznego przekazu są obecne we wszystkich przestrzeniach życia człowieka. Wpływają na jego rozwój, system wartości, niejednokrotnie kierują decyzjami i wyborami. Ich obecność jest odczuwana w życiu rodzinnym, we wspólnocie Kościoła, w edukacji dzieci i młodzieży. Towarzyszą ludziom zarówno w pracy, jak i w chwilach

21 Zob. Jan Paweł II, Orędzie Papieskie na Dzień Środków Społecznego Przekazu. Głosić Chrystusa w środkach społecznego przekazu na progu nowego tysiq̨clecia (2000), 151, w: Orędzia papieskie..., dz. cyt., s. 231-232; Jan Paweł II, Orędzie Papieskie na Dzień Środków Społecznego Przekazu. „Rozgłaszajcie to na dachach"; Ewangelia w epoce globalnej komunikacji (2001), 154-157, w: Orędzia papieskie..., dz. cyt., s. 235-239; Jan Paweł II, Orędzie Papieskie na Dzień Środków Społecznego Przekazu. Internet nowym forum dla głoszenia Ewangelii (2002), 158-163, w: Orędzia papieskie..., dz. cyt., s. $240-246$. 
odpoczynku. Jest zatem konieczne, aby twórcy mediów, zarówno świeckich jak i kościelnych, żyli z poczuciem misji wobec współczesnego odbiorcy, stając się tym samym współodpowiedzialnymi za właściwe ich wykorzystanie.

Chociaż w encyklice papieża Jana Pawła II Centesimus annus nie znajduje się wprost odniesienie do środków społecznego przekazu jako do pierwszego areopagu, na którym przemawia współczesny człowiek, to jednak trudno oprzeć się wrażeniu, że media również należy zaliczyć do tzw. „rzeczy nowych”. Refleksja pastoralna zmierza do tego, żeby nie pozostawić człowieka samemu sobie w jego trosce o kształtowanie swojego życia i w poszukiwaniu odpowiedzi na rodzące się pytania lub dylematy. Środki społecznego przekazu są bez wątpienia wielkim dobrodziejstwem współczesności. Pozostawione jednak same sobie, w atmosferze niczym nieskrępowanej wolności, mogą stać się zniewoleniem dla człowieka i zamiast wpływać pozytywnie na jego rozwój, staną się przyczyną jego degradacji. Stąd zatem wypływa nieustanna troska Kościoła o konieczność formowania w duchu chrześcijańskim nie tylko odbiorców mediów, lecz także ich właścicieli i pracowników. 